\title{
Non-economic Indirect Benefits of Road on Rural Households in West Bengal
}

\author{
Joyoti Gayen* and Debashis Sarkar
}

Institute of Agriculture, Visva-Bharati, Sriniketan-731236, West Bengal, India

*Corresponding author: joyoti_gn@rediffmail.com

\begin{abstract}
It is a well known fact that majority of poor people in the world live in rural areas where the level of public infrastructure especially roads is low. Provision of good road network is essential for the development of any country. Inadequate roads and poor road access results in high transportation cost, limits the uses of local markets, limits the purchase of consumer goods and opportunities for non-farm employments, reduces opportunities for new business and entrepreneurship, hinders social mobility and interaction, political participation, reduces access to credit, high quality inputs and constraints access to other social infrastructures such as education, health facilities etc. which are important for socio-economic development of the rural mass. In this view, an attempt has been made in this study to consider the benefits of rural roads apart from income and employment pattern of the households of West Bengal. It has been found that rural infrastructure like roads and railways significantly affect the socioeconomic aspects of rural people. The study also reveals that high road density and population density positively influences the educational level; proximity of main road and rail station improves the standard of living by increasing the access to health, education, market facilities, social mobility, affecting land holding pattern, political participation and other indirect benefits apart from change in income, employment, consumption pattern. When the above parameters are considered separately, group mean statistical analysis shows a statistically significant result for the group of rural households living in the vicinity of roads and rail stations with relatively better connectivity.
\end{abstract}

Keywords: Public infrastructure, rural roads, socio-economic development, education, health facilities, social mobility, land holding, income, consumption, group mean.

Infrastructure investments contribute largely to economic growth and raise the quality of life. Creation of an infrastructure generates external economies, wide spread benefits thereby improving the standard of living. Similarly rural infrastructure mainly rural roads are crucial for overall socioeconomic development of rural areas. Public goods like road might not have immediate effect in terms of socio-economic development but considering its multiplier effects, road has positive effects in long run not only in terms of economic but also social aspects. In rural areas inadequate roads and poor road access constraints the rural poor in terms of access to other social infrastructures like education, health facilities along with other opportunities associated with connectivity. In other way round it can be said that rural infrastructures mainly rural roads is a basic condition for social development and economic growth without which poverty will reign.

The word "Infrastructure" used in development economics has become a popular word and is often used loosely. Infrastructure generally refers to "Physical infrastructure" and "Social overhead capital". Directly productive economic infrastructure/or physical infrastructures that are basic to the carrying out of a wide variety of economic activities and social infrastructure results in creating a healthy working environment as well as by facilitating human capital formation in rural areas. Physical infrastructures or economic 
infrastructures like roads, railways, ports, airports, power \& telecommunication strengthen the economy, boost investments, attract prospective entrepreneurs and help in alleviation of poverty and unemployment through numerous positive forward and backward linkage effects on the primary, secondary and tertiary sectors of the economy.

It is a well known fact that improved accessibility pertains to various direct and indirect benefits in long run both in rural and urban area. Indirect benefits associated with the development of rural roads consist of increase in employment opportunities, opening up of alternative non-farm employment resulting in more diversified income structure and more diversified sources of income other dimensions of well being like improved access to health facilities, rising the educational status, more of social interactions and mobility, political participation, access to markets, rise in consumption expenditure, increase in land prices resulting from a better accessibility between rural and urban areas, rise in credit facilities etc.

Rural roads play an important role in provision of physical access. Rural people face obstacles in social services delivery such as health, education and related social services (Escobal and Ponce, 2002). Effects of road improvements increase accessibility of health care facilities (Airey, 1989). Socio-economic effects of road improvement reveal the economic benefits and opportunities that raises the asset value, facilitating trade and business opportunities (Singru, 2007). Rural roads and transportation system are essential for sustaining agricultural development. Study reveals a correlation between roads and poverty reduction. In India this correlation between roads and poverty reduction is ranked at the top of the scale (Singru, 2007). Similar studies say impact of road improvement and construction reduce poverty by increasing the income earning opportunities of the poor and by reducing the cost of the goods they consume (Menon, 2007). Another past research came out with the suggestion that the construction of roads encourage economic growth by stimulating economic activity in rural areas (Border, Taylor and McNamara, 1992). A past study shows how rural infrastructure raises the travel frequency of Households by $37 \%$, increases poor and vulnerable household income up to $50 \%$ allowing drastic reduction of male seasonal migration, enhanced loan repayments and initiation of several village savings and loan groups. Road helps labour and product markets to function better. It has been widely argued that rural roads increase job opportunities leading to a more diversified income structure and these increased economic activities stimulate demographic changes thereby altering socioeconomic practices (Paudel, 2014). Importance of rural roads for development and raising the standard of living by influencing the social variables like access to health, education facilities, markets, social mobility, and more opportunities for new business, entrepreneurship, political participation is enormous. Benefits of rural roads are generally perceived largely as social rather than economic in nature. Apart from a positive impact on household income, employment, consumption expenditure pattern rural poor are benefitted indirectly by other types of intervention like health services, access to educational institutions, credit facilities etc. (Songco, 2002). Other previous comparison study between households and towns located near rehabilitated roads under different Public programs with households /towns located far off from rehabilitated rural roads reveal the fact that along with other benefits it increases in access to key social services (Cuanto, 2000). It has been observed from the past studies that in addition to creation of employment opportunities for local people through facilitation of small business and industries in long run, providing temporary employment opportunities through road construction works as roads facilitate utilization of existing socio-economic services such as education and health will enhance human capital of the poor thereby increasing livelihood capabilities. Roads play a vital role to enhance productivity by fostering technology and information flows (Terefe, 2012). Thus rural roads are generally regarded as instrumental in creating opportunity, facilitating empowerment, enhancing security and improving the standard of living in rural areas. In this background, an attempt has been made in this study to consider the indirect social benefits associated with rural roads as enjoyed by the households.

\section{DATABASE AND METHODOLOGY}

The study has been conducted based on both primary and secondary data. Secondary data has been collected from different sources i.e., Census 
and Statistical Abstract published by Bureau of Applied Economics and Statistics, Government of West Bengal. The primary data has been collected from two districts. At first, the road density of all districts of West Bengal has been calculated based on the secondary data. Then all the districts have been sub-divided into two groups i.e., high and low road density. Howrah district with high road density and Purulia district with low road density have been selected randomly. In the next stage, the list of blocks of the selected districts has been collected and one block from each district i.e., Uluberia-I from Howrah and Para from Purulia have been selected randomly. The list of all villages of the selected blocks has been collected and subdivided into two groups i.e., (i) proximity to main road \& rail station along with presence of paved road and mud road within the villages and a high population density second group of villages have been selected which are (ii) away from main road \& rail station and which do not have paved road within the village but a high population density (According to Census data). Then two villages from each group i.e. four villages from each district have been selected randomly. In the next stage, the list of the households of the selected villages has been collected and 40 households from each village i.e., 160 households from each district have been selected. Finally, 320 households have been selected as the ultimate sample unit of the study.

As we have described earlier villages under study have been grouped into two categories and accordingly 4 villages have been chosen randomly from each district 2 of each categories. The primary data has been collected using structured questionnaires and the data have been analysed by employing descriptive statistics like tables, graphs, percentage, mean, standard deviation, coefficient of variation and inferential statistics like "Group mean comparison analysis" tool to see whether the Group means are statistically significant /different from each other.

For Group mean analysis first two groups have been defined. One group of households are those who are residing near main road and railway station and other group of households are those who reside relatively away from main road and rail station with poor access. First intra district comparison within the two groups of villages in each district has been done for the parameters under study i.e., 160 samples from each district has been selected, 80 sample of each group.

Thus in Howrah (group " 0 "- Representing villages away from main road and rail stations, Group "1" - Representing villages near main road and rail stations) total 160 number of households under study, 80 samples from each group and 80 number of households from group 0 and 80 number of households from group 1 were studied. At Purulia (group " 0 "-Representing villages away from main road and rail stations, Group "1" - Representing villages near main road and rail stations) total 160 households under study, 80 samples from each group and 80 number of households from group 0 and 80 number of households from group 1 were examined. After intra comparison all the 320 Households under study irrespective of districts have been taken up and grouped into 2 categories depending on their nearness to main road and rail station and having paved road, mud-road within the villages themselves. Thus for ALL (group " 0 "Representing villages away from main road and rail stations, Group "1" - Representing villages near main road and rail stations) total 320 number of samples in all the 8 villages from 2 districts were studied. Relevant parameters are tested and measured thereafter.

\section{RESULTS AND DISCUSSION}

There is significant empirical evidence that there exists a positive correlation between infrastructure networks, including roads and GDP per capita or growth rates. Hence the road network is frequently considered as a prime index of development. The main aim of road development provides infrastructural facilities and social transformation (Gerald, 1986). Development of a road network is indicated as the most important need for benefits to trickle down to local inhabitants (Singh and Chauhan, 1984; Werner and Lucious, 1992). Improved accessibility increases opportunities to access education leading to higher percentage of people with basic education and literacy which has been associated with better productivity. Rural road development leads to higher secondary schooling enrolment for boys and girls (Singru, 2007). Impacts from rural road identifies very clear causal linkages between rehabilitated rural road infrastructure and 
access to education as well a substantial increase in the use of public health services (Levy, 1996). So access to education and health services undoubtedly has a positive impact on the household welfare. Educational qualification shown in Tables 1 and 2 reflect that irrespective of the district, the households have better educational status that has proximity to main road and rail station. It can be said that high road density influences the educational level.

Fig. 1 clearly depicts that more than 50\% (58.14\%) of the total number of respondents have educational qualification. Middle school level of education and higher ups who reside near main road and rail station with a relatively good connectivity on the contrary people living in those villages away from road connectivity i.e. more than 50\% (57.5\%) of the respondents have educational qualification up to primary level. Apart from the tabular and graphical analysis for the parameter "Educational status" of the households under study "Group mean comparison statistics" has been used as a tool for inferential statistics.

\section{Group Statistics: Average Educational Status of Households under study}

At first, average educational status of the household has been defined as: Average educational status of household $=$ (total of each of the family member above 7 years of age *their respective qualification)/ total number of family members (Note: 0 indicating illiterate 1 indicating literate and so on with 6 as Graduation and above).

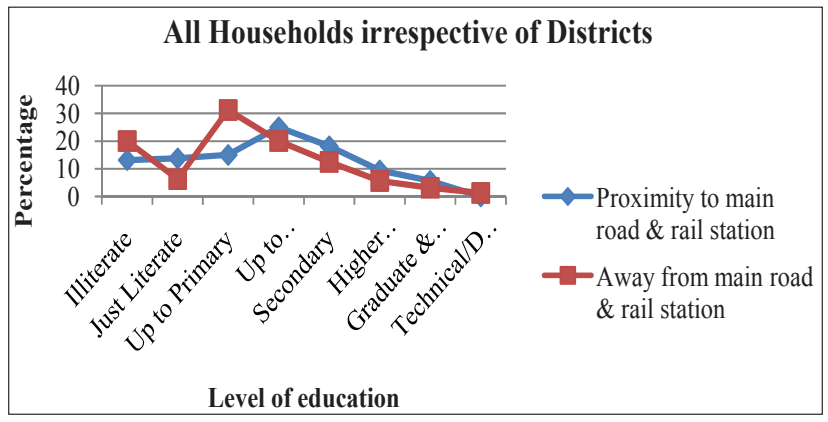

Fig 1: Graphical presentation of the level of education (in \%) of the respondents of "All" the sample households irrespective of districts

Table 1: Level of education of the respondents (in \%)

\begin{tabular}{ccccccc}
\hline Level of Education & \multicolumn{2}{c}{ Howrah } & \multicolumn{2}{c}{ Purulia } & \multicolumn{2}{c}{ All } \\
\cline { 2 - 7 } & $\begin{array}{c}\text { Proximity to } \\
\text { main road \& rail } \\
\text { station }\end{array}$ & $\begin{array}{c}\text { Away from } \\
\text { main road \& } \\
\text { rail station }\end{array}$ & $\begin{array}{c}\text { Proximity to } \\
\text { main road \& } \\
\text { rail station }\end{array}$ & $\begin{array}{c}\text { Away from } \\
\text { main road \& } \\
\text { rail station }\end{array}$ & $\begin{array}{c}\text { Proximity to } \\
\text { main road \& } \\
\text { rail station }\end{array}$ & $\begin{array}{c}\text { Away from } \\
\text { main road \& } \\
\text { rail station }\end{array}$ \\
\hline Illiterate & 6.25 & 10 & 20 & 30 & 13.13 & 20 \\
Just Literate & 15 & 11.25 & 12.5 & 1.25 & 13.75 & 6.25 \\
Up to Primary & 16.25 & 41.25 & 13.75 & 21.25 & 15 & 31.25 \\
Up to middle school & 26.25 & 15 & 23.75 & 25 & 25 & 20 \\
Secondary & 18.75 & 11.25 & 17.5 & 13.75 & 18.13 & 12.5 \\
Higher Secondary & 10 & 6.25 & 8.75 & 5 & 9.38 & 5.63 \\
Graduate \& above & 7.5 & 3.75 & 3.75 & 2.5 & 5.63 & 3.13 \\
Technical/Diploma & - & 1.25 & - & 1.25 & - & 1.25 \\
\hline
\end{tabular}

Source: Field Survey

Table 2: Group statistics for average educational status of the households

\begin{tabular}{|c|c|c|c|c|c|c|c|}
\hline \multirow[b]{2}{*}{ District } & \multirow{2}{*}{$\begin{array}{l}\text { Type of } \\
\text { Group }\end{array}$} & \multicolumn{3}{|c|}{ Group Statistics } & \multicolumn{3}{|c|}{ t- Test for Equality of Means } \\
\hline & & $\mathbf{N}$ & Mean & SD & $t$ & Sig. (2 tailed) & Level of significance \\
\hline \multirow[t]{2}{*}{ Howrah } & 0 & 80 & 3.00 & 0.79 & 0.12 & 0.090 & $10 \%$ \\
\hline & 1 & 80 & 4.78 & 0.10 & & & \\
\hline \multirow[t]{2}{*}{ Purulia } & 0 & 80 & 2.52 & 1.03 & -2.20 & 0.030 & $5 \%$ \\
\hline & 1 & 80 & 2.88 & 0.97 & & & \\
\hline \multirow[t]{2}{*}{ All } & 0 & 160 & 2.72 & 0.85 & -1.55 & 0.032 & $5 \%$ \\
\hline & 1 & 160 & 3.75 & 0.96 & & & \\
\hline
\end{tabular}

Note: Equal variances assumed; Group 0-Villages away from main road and rail station, Group 1 -Villages near main road and rail station 
When we compare the group mean values for "average educational status" of the households under study of those group of people residing near main road and rail station having good connectivity versus those households residing at relatively remote places with poor communication system, the result is shown in Table 2. First intra district comparison has been done between the two groups of households (Categorized into 1 and 2 on the basis of their location) then comparison has been done for all the samples taken together irrespective of districts based only on their residential location (Divided into group 1 and 2). In all the cases it has been found that the mean value of the parameter "Average educational status of the household" is higher for those households who reside near main road and rail station having comparatively better connectivity than those who reside at poorly connected villages. Whether these two means differ statistically or not is observed from t- test information table. For both intra district comparison and comparison irrespective of districts (all samples together) we find that there exists a statistically significant difference between two group mean values. If we see the last row where all the 320 households are taken and comparison has been done after grouping them into 1 and 2, it shows that the mean value of two groups for "Household's educational status" is 2.72 in case of villages away from main road and railway station and 3.75 almost 4 (taking round of value) in case of villages near main roads and railway station. 't-test' result shows that the ' $p$ ' value is .032 and degrees of freedom are 318. So the two group means for educational status of the household under study significantly differs at $5 \%$ level of significance.

Therefore it may be concluded that presence of rural roads and rail station adjacent to village has significant impact on the educational status of the households. From both tabular analysis and inferential analysis, the same observation has been reflected. Higher percentage of population with better educational status resides near main road and railway stations having high road density. Enrolment of the boys and girls in high school, colleges and other technical institution is also better in those households living adjacent to main road and rail station nearby. Therefore rural roads have a significant impact on the educational status of the households.
In a similar way, while considering the impact of rural roads on access to health services same results have been found. Since the number of district hospitals, primary health centres, community health centres etc. do not increase every year therefore households under study availing to different healthcare facilities outside village/Gram Panchayat (GP) have been measured by 'health score' obtained by the sample households tested statistically using 'Group mean comparison' method. 'Health score' has been taken as 1 if the members of any of the households go outside village/GP for treatment and the household gets the score 0 if the members of any of the households do not go outside village for availing public health services/treatment. The following tables reveal that there is a significant change in the use of public health services outside village/GP in case of those villages where there is road connectivity. The mean value of "Health score" is also high (more towards 1) for those residing in the vicinity of road access and having railway connectivity. The result is statistically significant also. This holds true for both the districts when intra district group mean comparison has been done and also for all the samples irrespective of districts while grouping the samples into two broad categories on the basis of presence of roads and vicinity to railway transportation. Table 3 shows the result of the analysis.

Means of two groups for 'Health Score' of the households under study is 0.50 in case of villages away from main road and railway station and 0.69 (nearing to 0.70 ) in case of villages near main roads and railway station at Howrah district. Whether these two means differ statistically or not is observed from $t$ - test. The result shows that the ' $p$ ' value is 0.016 and degree of freedom is 158 . So the two group means for health score of the households under study significantly differs at $5 \%$ level of significance. Similarly for 'Health Score' of the Households under study is 0.52 in case of villages away from main road and railway station and 0.61 in case of villages near main roads and railway station at Purulia. And the two group means differ at $10 \%$ level of significance.

When we compare the group mean value for the parameter 'Health Score' of all the sample households taken together irrespective of districts and then 
Table 3: Group statistics for health score of the households under study

\begin{tabular}{cccccccc}
\hline District & Type of & \multicolumn{3}{c}{ Group Statistics } & \multicolumn{3}{c}{$\mathbf{t}$ - Test for Equality of Means } \\
\cline { 2 - 7 } & Group & $\mathbf{N}$ & Mean & SD & $\mathbf{t}$ & Sig. (2 tailed) & Level of significance \\
\hline \multirow{2}{*}{ Howrah } & 0 & 80 & 0.50 & 0.50 & -2.44 & 0.016 & $5 \%$ \\
& 1 & 80 & 0.69 & 0.47 & & & $10 \%$ \\
Purulia & 0 & 80 & 0.52 & 0.50 & -1.12 & 0.067 & $5 \%$ \\
& 1 & 80 & 0.61 & 0.49 & & & \\
All & 0 & 160 & 0.51 & 0.50 & -2.51 & 0.013 & \\
& 1 & 160 & 0.65 & 0.48 & & & \\
\hline
\end{tabular}

Note: Equal variances assumed; Group 0-Villages away from main road and rail station, Group 1 -Villages near main road and rail station.

grouping them into two categories according to their location with respect to connectivity, mean value for health score is 0.51 in case of villages away from main road and railway station (Group 0) and 0.65 in case of villages near main roads and railway station (Group 1) irrespective of districts where they are situated. Whether these two means differs statistically or not is observed from independent samples t-test. The result shows that the ' $p$ ' value is 0.013 and degree of freedom is 318 . So the mean value for 'Health Score' of two groups significantly differs at $5 \%$ level of significance.

From the statistics it may be concluded that with improvement in communication (due to nearness of roads and railway station and presence of village road within) people availing to different healthcare facilities (Like Hospitals, nursing homes, polyclinics etc) increases which is being reflected in the above statistical analysis being measured by "Health score". Accordingly it is higher to those who reside near main roads and rail station and having better communication and awareness. And the result is statistically significant.

Other than the above positive impacts of road intervention on Education and Health care services, the selected roadside villages when compared with those villages situated relatively far from main roads and rail station are influenced significantly in certain other indirect social benefits of the households like access to various Government programmes, social and political participation apart from the indirect economic changes in the pattern of employment, income, asset position, credit services, diversification of income sources and induced changes in consumption expenditure. Tables 4, 5 and 6 show the changes in those parameters for the households under study. These indirect noneconomic benefits are of most importance for wellbeing of the rural masses.

\section{Comparison according to social mobility of the households outside village/Gram Panchayat}

Cosmopoliteness of the people residing in villages near main road and rail station with good communication system and those people residing in comparatively remote villages with poor access has been tried to capture by making an index of cosmopoliteness. Thus cosmopoliteness index $=$ (number of family members visiting outside GP how often he/they visit being coded by number)/ Total number of family members. How often the members of a household visit outside GP being coded by a four point rating scale with never as zero and most often as four (most often $=4$, often $=3$, sometimes $=2$, rarely $=1$, Never $=0$ ).

Two group mean value for 'Cosmopoliteness index' of the households under study is 2.69 in case of villages away from main road and railway station and 4.36 in case of villages near main roads and railway station at Howrah district. Whether these two means differ statistically or not is observed from $\mathrm{t}$ - Test information table. The result shows that the ' $p$ ' value is 0.000 and degree of freedom is 158 . So the two group means for cosmopoliteness index of the households under study significantly differs at $1 \%$ level of significance

Similarly for 'Cosmopoliteness index' of the households under study is 3.73 in case of villages away from main road and railway station and 5.19 in case of villages near main roads and railway station at Purulia. And the two group means differ statistically at $1 \%$ level of significance.

When we compare the group mean value for 
Table 4: Group statistics for cosmopoliteness index of the households

\begin{tabular}{|c|c|c|c|c|c|c|c|}
\hline \multirow[t]{2}{*}{ District } & \multirow{2}{*}{$\begin{array}{l}\text { Type of } \\
\text { Group }\end{array}$} & \multicolumn{3}{|c|}{ Group Statistics } & \multicolumn{3}{|c|}{ t- Test for Equality of Means } \\
\hline & & $\mathbf{N}$ & Mean & SD & $t$ & Sig. (2 tailed) & Level of significance \\
\hline \multirow[t]{2}{*}{ Howrah } & 0 & 80 & 2.69 & 0.93 & -8.34 & .000 & $1 \%$ \\
\hline & 1 & 80 & 4.36 & 1.52 & & & \\
\hline \multirow[t]{2}{*}{ Purulia } & 0 & 80 & 3.73 & 1.47 & -7.08 & .000 & $1 \%$ \\
\hline & 1 & 80 & 5.19 & 1.10 & & & \\
\hline \multirow[t]{2}{*}{ All } & 0 & 160 & 3.21 & 1.34 & -10.23 & .000 & $1 \%$ \\
\hline & 1 & 160 & 4.77 & 1.39 & & & \\
\hline
\end{tabular}

Note: Equal variances assumed; Group 0-Villages away from main road and rail station, Group 1 -Villages near main road and rail station

Table 5: Average number of visits to various places outside gp by the members of the households

\begin{tabular}{ccccccc}
\hline $\begin{array}{c}\text { Average number of } \\
\text { times visiting outside } \\
\text { GP /month }\end{array}$ & \multicolumn{2}{c}{$\begin{array}{c}\text { Howrah (\% of HHs visiting } \\
\text { outside) }\end{array}$} & $\begin{array}{c}\text { Purulia (\% of HHs visiting } \\
\text { outside) }\end{array}$ & \multicolumn{2}{c}{$\begin{array}{c}\text { All (\% of HHs visiting } \\
\text { outside) }\end{array}$} \\
\cline { 2 - 7 } & Near Road & Away Road & Near Road & Away Road & Near Road & Away Road \\
\hline $0--4$ & 27.5 & 47.5 & 31.25 & 55.00 & 29.38 & 51.25 \\
$4--8$ & 35.00 & 30.00 & 52.5 & 25.00 & 43.75 & 27.5 \\
$8--12$ & 17.50 & 16.25 & 7.5 & 13.75 & 12.5 & 15.00 \\
12 and above & 20.00 & 6.25 & 8.75 & 6.25 & 14.37 & 6.25 \\
Total & 100 & 100 & 100 & 100 & 100 & 100 \\
\hline
\end{tabular}

Source: Field survey

Table 6: Group statistics for social participation score of the households

\begin{tabular}{cccccccc}
\hline \multirow{2}{*}{ District } & Type of & \multicolumn{3}{c}{ Group Statistics } & \multicolumn{3}{c}{$\mathbf{t}$ - Test for Equality of Means } \\
\cline { 3 - 7 } Group & $\mathbf{N}$ & Mean & SD & $\mathbf{t}$ & Sig. (2 tailed) & Level of significance \\
\hline \multirow{3}{*}{ Purulia } & 0 & 80 & 0.43 & 0.50 & -2.74 & 0.007 & $1 \%$ \\
& 1 & 80 & 0.64 & 0.48 & & & \\
& 0 & 80 & 0.65 & 0.49 & -0.493 & .623 & $>10 \%$ (insignificant) \\
All & 1 & 80 & 0.77 & 0.48 & & & $5 \%$ \\
& 0 & 160 & 0.53 & 0.50 & -2.282 & .023 & \\
\hline
\end{tabular}

Note: Equal variances assumed; Group 0-Villages away from main road and rail station, Group 1 -Villages near main road and rail station

the parameter 'Cosmopoliteness index' of all the sample households taken together irrespective of districts and then grouping them into two categories according to their location with respect to connectivity, mean value is 3.21 in case of villages away from main road and railway station (Group 0) and 4.77 in case of villages near main roads and railway station (Group1) irrespective of districts where they are situated. Whether these two means differs statistically or not is observed from independent samples t-test. The result shows that the ' $p$ ' value is 0.000 and degree of freedom is 318. So the mean value for 'Cosmopoliteness index' of two groups significantly differs at $1 \%$ level of significance.

Hence we see from the analysis how connectivity reduces distance among people and brings the people of remote area to the mainstream of life. It is clearly seen that the members of households who reside in those villages near main road with rail station nearby visit the town/city/district head quarter/market very often than those households who reside at relatively poorly connected villages.

The same has been reflected from the tabular analysis also showing the percentage distribution. 
Table 5 shows how the distribution of the households differs according to the average number of visits to various places outside GP by the members of the households. As the mobility of the people increase, social participation of the people also raises that has been captured through 'Social participation score 'of the sample households.

\section{"Social Participation Score (SP)" of the members of Households under study}

Social participation of the members of the household has been categorized by 0 or 1 according to their participation in meetings of GP, PS, ZP, MLA/MP, others (SHG) etc and has been tested statistically by group mean comparison method. Whether any significant difference exist in the mean values among two groups of households (one residing near main road and rail station with good communication system and other residing at remote villages) in regard to social participation score in 2 districts has been observed from t-test for equality of means. Finally the same test has been carried out taking all the households irrespective of districts only sub-grouping them according to their vicinity to main road and rail station. Results of the analysis are shown in Table 6.

In first row for Howrah district mean of two groups for "Social Participation" of the households under study is 0.43 in case of villages away from main road and railway station and 0.64 in case of villages near main roads and railway station. Independent samples t-test result shows that the mean values for two groups significantly differ at $1 \%$ level of significance ('p' value is 0.007 ).

At Purulia district intra district comparison result shows that although the mean values for 'Social participation score' differs for two groups of households (group 0 and group 1 depending on their residential location), the t-Test information table shows that the group means does not differ significantly. ' $p$ ' value being 0.623 shows that the result is not statistically significant at Purulia. There may be many other factors influencing the social participation of the villagers.

When the comparison is made taking all the samples together and grouping the samples into two categories 1 and 2 depending on their residential location, it has been found that the mean values for two groups of households differ. It is 0.53 in case of villages away from main road and railway station and 0.65 in case of villages near main roads and railway station irrespective of districts where they are situated. Whether these two means differ statistically or not have been observed from t-test information table. The result shows that the ' $p$ ' value is 0.023 and degree of freedom is 318 . So the two group mean values for "Social participation score" of the household under study differ significantly at $5 \%$ level of significance. Table- 7 shows how the distribution of the households differs according to the social participation of the respondent or other member of the family.

Table 7: Distribution of the households according to social participation

\begin{tabular}{|c|c|c|c|c|c|c|}
\hline \multirow[t]{2}{*}{ Participation as } & \multicolumn{2}{|c|}{$\begin{array}{c}\text { Howrah (\% of } \mathrm{HHs} \\
\text { participation) }\end{array}$} & \multicolumn{2}{|c|}{$\begin{array}{c}\text { Purulia (\% of } \mathrm{HHs} \\
\text { participation) }\end{array}$} & \multicolumn{2}{|c|}{ All (\% of HHs participation) } \\
\hline & Near Road & Away Road & Near Road & Away Road & Near Road & Away Road \\
\hline GP member & $10 \%(8)$ & $3.75 \%(3)$ & $3.75 \%(3)$ & $0(0)$ & $6.88 \%(11)$ & $1.88 \%(3)$ \\
\hline Attend GP meetings & $56.25 \%(45)$ & $51.25(41)$ & $47.5 \%(38)$ & $36.25 \%(29)$ & $51.88 \%(83)$ & $43.75 \%(70)$ \\
\hline Panchayet Samity member & $3.75 \%(3)$ & $0(0)$ & $0(0)$ & $0(0)$ & $1.88 \%(3)$ & $0(0)$ \\
\hline Attend PS meetings & $42.5 \%(34)$ & $32.5 \%(26)$ & $31.25 \%(25)$ & $22.5 \%(18)$ & $36.88 \%(59)$ & $27.5 \%(44)$ \\
\hline Attend MLA/MP meetings & $42.5 \%(34)$ & $26.25 \%(21)$ & $48.75 \%(39)$ & $37.5 \%(30)$ & $45.63 \%(73)$ & $31.88 \%$ (51) \\
\hline Member of SHG & $60 \%(48)$ & $35 \%(28)$ & $52.5 \%(42)$ & $27.5 \%(22)$ & $56.25 \%(90)$ & $31.25 \%(50)$ \\
\hline Attend meetings of SHG & $57.5 \%(46)$ & $35 \%(28)$ & $52.5 \%(42)$ & $27.5 \%(22)$ & $55 \%(88)$ & $31.5 \%(50)$ \\
\hline Other & $11.25 \%(9)$ & $7.5 \%(6)$ & $8.75 \%(7)$ & $6.25 \%(5)$ & $10 \%(16)$ & $6.88 \%(11)$ \\
\hline
\end{tabular}

Note: In several cases the respondents or other members of their family have multiple memberships. They often visit to more than one kind of meeting so the total percentage in the above table is greater than 100, and the number of households participating in various social activities is more than $N$. ( $N=80$ in each kind of location near or away depending on its connectivity in both the districts and similarly $N=160$ in each case when all the villages taken together irrespective of districts, considering on its location near road or away from main road) 
From the statistical analysis (both tabular and inferential statistics), it may be concluded that with improvement in communication i.e., due to nearness of roads and railway station and presence of village road within, social participation of the households become higher in case of those who reside near main roads and rail station having better communication. And the result is statistically significant.

So the result of descriptive analysis reflects the same. When we compare all the 8 villages depending on its location near to main road and rail station and away from main road and railway station irrespective of the district, we find that those who reside in villages near main road and railway station having good connectivity, average number of times of visit to different places outside GP by the members of these households is more.

As the mobility of the people increase their interaction with the outer world increases. This enhances their knowledge of outer world, creates awareness and motivation for improving their standard of living which is reflected in this study. It has been found how improved communication system affects access to different government programmes, reduction of open defecation system by usage of more sanitation facility within household premises. Fig. 2 shows graphical representation of the household access to various government programmes/schemes depending on their location.

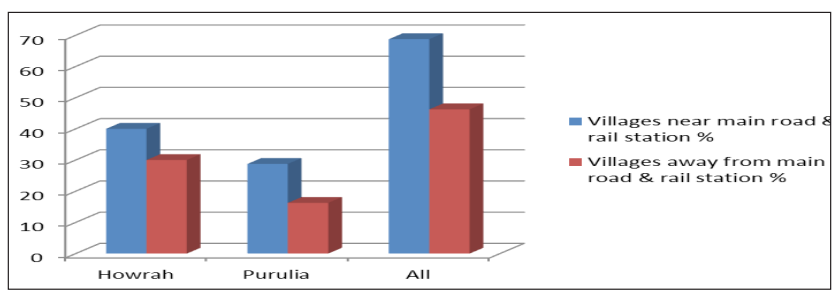

Fig. 2: Percentage-wise distribution of households according to availability of different government programmes
From the graphical representation, it is clearly seen how social interaction increases knowledge and awareness among people leading to more access to various government programmes. Good connectivity in rural areas increases the awareness of the people which in turn contributes to improved health condition by reducing practice of open defecation system. Maintenance of this better health and hygienic environment increases labour productivity in long run. This is an indirect benefit of rural roads and communication. Fig. 3 shows the graphical representation of percentage of households having permanent sanitation facility.

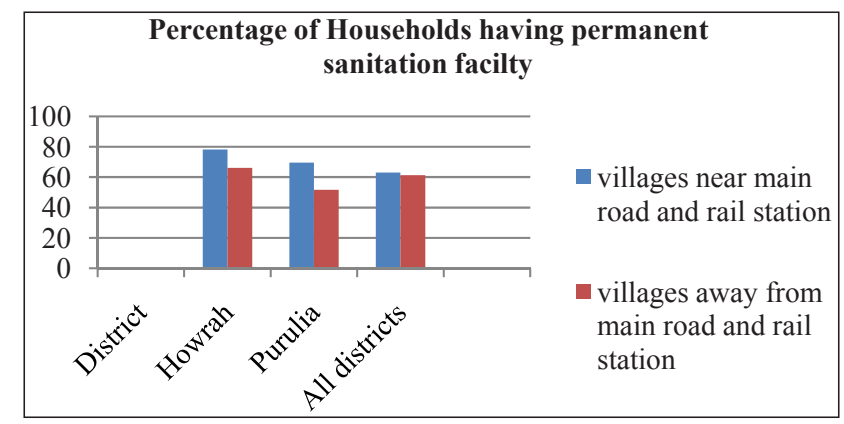

Fig. 3: Percentage of households having permanent sanitation facility

Using 'Group mean comparison method' analysis of sanitation condition of the sample households under study has also been captured. It has been measured by presence of sanitation facility within the house (pucca or kachha). Households have been scored by 0 or 1 according to the absence/presence of sanitation facility and has been tested statistically by group mean comparison method to see whether any significant difference exist in the mean values among two groups. Finally the same test has been carried out taking all the households irrespective of districts only sub-grouping ( $0 \& 1)$ them according to their vicinity to main road and rail station.

Table 8: Group statistics for sanitation score of the households

\begin{tabular}{|c|c|c|c|c|c|c|c|}
\hline & \multirow{2}{*}{$\begin{array}{l}\text { Type of } \\
\text { Group }\end{array}$} & \multicolumn{3}{|c|}{ Group Statistics } & \multicolumn{3}{|c|}{ t- Test for Equality of Means } \\
\hline & & $\mathbf{N}$ & Mean & SD & $\mathbf{t}$ & Sig. (2 tailed) & Level of significance \\
\hline Howrah & 0 & 80 & 0.73 & 0.44 & -0.934 & 0.035 & $5 \%$ \\
\hline \multirow[t]{2}{*}{ Purulia } & 0 & 80 & 0.36 & 0.48 & -2.573 & 0.011 & $5 \%$ \\
\hline & 1 & 80 & 0.56 & 0.50 & & & \\
\hline
\end{tabular}

Note: Equal variances assumed; Group 0-Villages away from main road and rail station, Group 1 -Villages near main road and rail station 
From the above inferential statistics it may be concluded that with improvement in communication system mean value of sanitation score is accordingly higher for those who reside near main roads and rail station (having better communication system and awareness) indicating more usage of sanitation system and thereby reducing the practice of open defecation and the result is statistically significant. Thus from both the graphical representation and inferential statistics, it has been found that villages near main road and rail station have higher percentage and usage of sanitation facilities leading to an improved standard of living. Thus it may be inferred that improved communication system leads to more awareness of people thereby reducing open defecation habit. So the study clearly reflects how the degree of road access affects the comfort of the rural household indirectly.

\section{CONCLUSION}

As we have seen in several past studies that the impact of improved road accessibility is largely social leading to diversified livelihoods, this study reveals the same with a statistically significant result. Thus provision of rural roads results in increased mobility level which breaks isolation of village communities from the outside world. Improved accessibility gives the rural mass more opportunity of frequent interaction with the outer world thereby giving a sense of security by exchange of ideas, change in attitudes, and knowledge of new technology through more social contacts. Rural transportation system leads to good extension of services like access to better education and health service also. So it can be concluded that the physical infrastructure like rural roads act as a catalyst for both economic growth and development along with other significant social benefits

\section{REFERENCES}

Airey, T. 1989. The impact of road construction on hospital in-patient catchments in the Meru District of Kenya, Social Science and Medicine, 29(1): 95-106.
Border, J.M., Taylor, T.D. and McNamara, K.T. 1992. Quasi experimental designs for measuring impacts of developmental highways in rural areas, Southern Journal of Economics, 24(1):199-207.

Census 2011 and Statistical Abstract published by Bureau of Applied Economics and Statistics, Government of West Bengal, 2008.

Cuanto, I. 2000. Peru: Informe Final de Evaluaciondel Proyecto de Caminos Rurales. Reportepreparado para la Direcion de caminos Rurales. Lima: Ministerio de Transporte, Communicaciones, Vivenda y Construccion.

Escobal, J. and Ponce, C. 2002. The Benefits of Rural Roads: Enhancing Income Opportunities for the Rural Poor. GRADE Working Paper 40-I, Lima, pp. 52.

Gerald, G. 1986. Nepal's road network: A stimulus for economic development, Applied Geography and Development, 28: 8495.

Levy, H. 1996. Kingdom of Morocco: Socioeconomic influence of Rural roads: Fourth Highway Project. Impact Evaluation Report No.15808. The World Bank Operation Evaluation Department: Washington, D.C.

Menon, Jay. 2007. Does Road Improvement Reduce Poverty? A CGE Analysis for Lao PDR, Asian Development Bank Institute.

Singh, S. and Chauhan, V.S. 1984. Regionalisation for Rural Development and Planning, Independent Publishing Pvt. Ltd., Meerut.

Singru, Narendra. August 2007. Socioeconomic effects of Road Improvements, From the 2007 Sector Assistance Program Evaluation for the Transport Sector in IndiaFocusing on results, Operations Evaluation Department, Asian Development Bank.

Songco, J.A. 2002. Do Rural Infrastructure investments Benefit the Poor? Evaluating Linkages: A Global view, A Focus on Vietnam. Policy Research working paper Series 2796. Washington DC: World Bank.

Terefe, Lulit Aklilu. 2012. Impact of Road on Rural poverty evidence from fifteen rural villages in Ethiopia. Research paper. International Institute of Social sciences.

Werner, F. and Lucious, G.K. 1992. The influence of transportation infrastructure on the regional pattern of agriculture in West Africa, using as an example the impact of the minor road network in the Dan Hills region of the Ivory Coast, Applied Geography and Development, 39: 30-47. 